\title{
PHYSICAL ACTIVITY LEVELS OF ADULTS IN TWO COUNTIES OF HUNGARY IN VIEW OF SOCIODEMOGRAPHIC INEQUALITIES
}

\section{POZIOM AKTYWNOŚCI FIZYCZNEJ OSÓB DOROSŁYCH W DWÓCH REGIONACH WĘGIER W ŚWIETLE NIEROWNOŚCI SOCJODEMOGRAFICZNYCH}

\author{
Alexandra Makai ${ }^{1(A, B, C, D, E, F, C)}$, Kata Füge $^{2(A, B, E)}, Z_{i t a}$ Breitenbach $^{3(A, B, E)}$, Mária Figler $^{3(A, B, E, F)}$ \\ ${ }^{1}$ University of Pécs, Faculty of Health Sciences, Doctoral School of Health Sciences, Hungary \\ ${ }^{2}$ University of Pécs, Institute of Emergency Care and Pedagogy of Health, Faculty of Health Sciences, Hungary \\ ${ }^{3}$ University of Pécs, Faculty of Health Sciences, Institution of Nutritional Science and Dietetics, Hungary
}

Authors' contribution

Wkład autorów:

A. Study design/planning

zaplanowanie badań

B. Data collection/entry

zebranie danych

C. Data analysis/statistics

dane - analiza i statystyki

D. Data interpretation

interpretacja danych

E. Preparation of manuscript przygotowanie artykułu

F. Literature analysis/search wyszukiwanie i analiza literatury

G. Funds collection

zebranie funduszy

Tables: 1

Figures: 6

References: 31

Submitted: 11.05.2016

Accepted: 27.06.2016

\section{Summary}

Background. Decreased physical activity (PA), sedentary lifestyle and inappropriate dietary habits have been observed in modern societies in the past decades.

Material and methods. Data were collected in summer, 2014. The representative (by age \& gender) sample consisted of 910 adults. The research (entitled "E-Harmónia") was carried out in two Hungarian counties, Baranya and Zala. We developed a tablet-based survey to examine PA using the International Physical Activity Questionnaire (IPAQ) questionnaire and collected anthropometric data with body composition monitors. Data analysis was carried out with SPSS 22.0 for Windows. The significance level was set at $\mathrm{p}<0.05$.

Results. The sample size of adult participants was 910 , their mean age was $43.2 \pm 14.4$ years. We examined the level of physical activity in view of sociodemographic inequalities, like gender, age, education, marital status, employment form. Women and aged and young people were found to do carry out significantly less leisure time PA $(p<0.05)$. Furthermore, we found significant relationship in PA and education level, age and employment form of the adults $(\mathrm{p}<0.001)$

Conclusions. In the present study according to the IPAQ questionnaires results we found significant differences in physical activity level and sociodemographic parameters, which helps to identify different risk groups to increase the effectiveness of phyisical activity interventions.

Keywords: health, adults, physical activity

\section{Streszczenie}

Wprowadzenie. We współczesnych społeczeństwach w ostatnich dekadach zaobserwowano spadek poziomu aktywności fizycznej, siedzący tryb życia oraz nieodpowiednie nawyki żywieniowe.

Materiał i metody. Dane zebrano latem 2014 r. Próba reprezentatywna ( według wieku oraz płci) składała się z 910 osób dorosłych. Badanie (nazwane "E-Harmónia") zostało przeprowadzone w 2 węgierskich regionach, Baranya i Zala. Została stworzona aplikacja zawierajaca ankiete badajaca poziom aktywności fizycznej poprzez Międzynarodowy Kwestionariusz Aktywności Fizycznej (IPAQ). Zebrano także dane antropometryczne wraz z miernikami składu masy ciała. Analiza danych przeprowadzona została przy zastosowaniu SPSS 22.0 dla Windows. Poziom istotności został określony jako $\mathrm{p}<0.05$.

Wyniki. Próba zawierająca w sobie uczestników badania składała się z 910 osób, a średni wiek uczestników wynosił $43.2 \pm 14.4$. Przeanalizowano także poziom aktywności fizycznej w świetle socjodemograficznych nierówności, takich jak płeć, wiek, wykształcenie, stan cywilny, forma zatrudnienia. Jak wykazały badania, kobiety oraz osoby młode wykazują się znacznie niższą aktywnością fizyczną PA $(\mathrm{p}<0.05)$. Co więcej, analiza wykazała silny zwiazek pomiędzy aktywnością fizyczną oraz poziomem wykształcenia osób dorosłych ( $\mathrm{p}<0.001)$. Wnioski. W poniższej analizie, zgodnie z ankietami IPAQ wykazane zostały znaczne różnice $\mathrm{w}$ poziomie aktywności fizycznej oraz $\mathrm{w}$ parametrach społeczno-demograficznych, co jest pomocne w identyfikowaniu grup ryzyka dla podnoszenia efektywności działań w zakresie aktywności fizycznej.

Słowa kluczowe: zdrowie, dorośli, aktywność fizyczna 


\section{Introduction}

A large proportion of the modern, urban and individualised population leads a sedentary and inactive lifestyle. The modern lifestyle and many of the modern-world tools such as the computer and other devices of telecommunication and transportation decrease physical activity [1,2].

The European directive defines physical activity as „all bodily movements that result in energy expenditure higher than the resting level. This includes daily routine activities such as household jobs, shopping, work, and also hard physical work such as building constructions." ${ }^{1}$ The examinations by Péter Apor show that the first priority for inactive participants is to train the muscles so that aerob physical activities become available for them. Thus in the beginning 3x10 minutes of moderate activities, then $3 \times 15$ minutes similar activities are recommended from the 3-4th week, supplemented by resistance training [3]. According to the American guidelines, at least 150 minutes/week moderate activity or 75 minutes /week vigorous activity is required for healthy adults. Similarly, the European guidelines suggest minimum 30 minutes moderate training 5 days a week, and at least 3x20 minutes vigorous training to maintain the appropriate level of physical activity ${ }^{1}$.

Physical activity is closely connected to health status and quality of life [4,5]. Low quality of life and inappropriate health status are often associated with low levels of physical activity or inactivity. At the same time, an active lifestyle plays a preventional role in one's life. Also, carefully chosen forms of physical activity might have a supplementary role in the treatment of various diseases. Regular physical activity improves the cardiovascular system and also the body's ability for resistance [6]. Furthermore, regular physical activity also has a primary role in the prevention and treatment of various diseases (eg. diabetes, cardiovascular diseases, or cancer) $[2,1]$. Ramirez-Vélez points out that the risk of cardiovascular diseases decreases by $20-40 \%$ if the physical activity of middle-aged adults is at least moderate (3-6 METs) or the calorie use is minimum $100 \mathrm{kcal} /$ week [7]. However, despite all of their health preserving effects, even low-intensity physical activities are often missing from the lifestyle of the adult population, which is commonly due to the lack of training partner or professional support [8].

According to the WHO's concept of health, it should be examined at the physical, psychological and psychosocial level as well [9]. Physical activity influences all three dimensions positively - for example, according to the results of Neumann et al (2008) physical activity decreases the risk of dementia in older people; and Pikó et al (2008) proved that physical activity has positive effects on the symptoms of depression [8, 10]. These results also suggest that physical activity and its effects should be examined in all three dimensions of health.

Apart from the personal level, the effect of physical activity in relation to health status must also be examined at a societal and an economical level. The average age of life expectancy is constantly growing in most European countries, and we have to face the growing challenges of aging populations [11]. Life expectancy grew by 4 years in Central and Eastern European countries, and by 4.2 years in EU15 countries between 1990 and 2010 [12]. The number of healthy life years, a growing employment-to-population ratio, and a decreasing number of inactive population are gaining primary importance for aging populations. The number of healthy life years may be successfully increased through regular physical activity, which is also proved to result in lower economic burden for European societies [13].

\section{Socio-demographic determinants of physical activity}

Socio-demographic determinants of health status is in the focus of several research projects [14]. There are a number of determinants influencing health status that also make a difference in physical activity. Examinations on adolescents draw the attention to major socio-demographic differences: apart from age, gender also has a significant effect on habits regarding regular physical activity. Empirical studies constantly highlight the disadvantaged situation of women, especially in the age of adolescence $[15,16,17]$.

Apart from socio-demographic- and other behavioural factors, physical activity is also strongly related to dietary habits. Furthermore, Kim et al examined whether religion and social support influenced the level of physical activity, and found that social support influences physical activity in elderly people to a greater extent. This examination also found significant correlation between religion and physical activity, although the researchers emphasize that this connection should not be analysed by bivariate analysis, but they should be controlled and other socio-demographic variables should also be included. In their study, Kim and colleagues used multivariate regression analysis to map the joint effect of social support and religion on physical activity, on a sample including 546 participants [18].

Hosseinpor et al (2012) using the applied multivariate linear regression model, that the health status of

http://www.eufic.org/article/en/page/BARCHIVE/expid/basics-physical-activity/ (10/12/2015) 
women is significantly lower than that of men; and the employment rate influences the health status of men, which is also due the features of the sample: people living in the country and unemployed are overrepresented. These two factors significantly influence the quality of life and physical activity, usually in a negative manner. The researchers also examined national differences, and found that differences were bigger within the European societies compared to the African societies. All this proves that the 'one size fits all' principle does not work when it comes to health policy making: societal and national differences (at a social, economical, and cultural level as well) should be considered when health preservation and other interventional strategies are in the making [19].

Physical activity and age seem to be unambiguously connected. Sedentary lifestyle results in a lower level of physical activity in the elderly, especially after retiring. However, Croatian studies found that 55-64-year-old participants were more active physically than 15-24-year-olds, which seems to be due to late retirement or the high level of physical workers among late-middle aged people [20]. Thus age groups are advised to be considered separately when examining physical activity.

Looking at educational background, several studies point out that people with lower level of education tend to do more physical activity, usually as they are more often employed in the physical sector, thus they usually perform their physical activity during work [14]. However, new trends highlight that there is a significant correlation between high levels of physical activity and high socioeconomical status in developed societies, and those with a higher social status pay more attention to their own health status, consequently spend more time on - or have more time for - physical activity [21]. Higher levels of income correlate with more physical and recreational activities.

Research by Hernandez et al. (2010) show that in women, lower levels of physical activity is associated with higher life expectancy. Women do less sports and chose sport as recreation less often than men. The present study the IPAQ (International Physical Activity Questionnaire) results (N=38746) show that men had better results in walking and high intensity physical activity, while women more often chose moderate physical activity. Thus women are a significant target group at planning interventions on physical activity [22]. Furthermore, the connection between family status and physical activity should also be mentioned: those living with a spouse especially among elderly people - tend to do more sports than those who live alone [23]. The aim of our research was to examine the physical activity rate in two Hungarian counties, Baranya and Zala, in relation to the sociodemographic factors.

\section{Material and methods}

The aim of the present study was to analyse energy balance in two Hungarian counties (Baranya and Zala) using quantitative methodology. The data collection took place in 2014 and was carried out through a tabletbased survey. We calculated average energy intake by compiling lists of regularly eaten food and beverages. We calculated energy use by quantifying respondents' physical activity. Our sample was nationally representative according to age and gender in Hungary, we included 910 respondents aged 18-69. Data collection was completed in face-to-face interviews taken by 12 interviewers, and by tablets (computer-assisted interviews). Statistical analysis - using the SPSS v.22 software - included Kolmogorov-Smirnov normality test and chi-square tests. Results were considered significant when $\mathrm{p}<0.05$. The research project was approved by the Regional Scientific Ethical Committee of University of Pécs (approval number: 5430/2014).

\section{Research tools}

We applied a complex questionnaire during the survey, including demographic questions, a 72-hour nutrition diary, the Food Frequency Questionnaire (FFQ), the International Physical Activity Questionnaire's (IPAQ) long version for adults [24, 25], and the Food Choice Questionnaire (FCQ). The survey was supplemented by anthropometric data collection, using the Omron BF511 body composition measurement tool. Our dependent variables were the measurements of physical activity based on IPAQ. This questionnaire does not only summarize sport activities, but also includes information on physical activities such as work, home activities and transportation. Sedentary time is also included and analysed. Our independent variables were gender, age (age-group), level of education, work and family status. 


\section{Results}

\section{Sample}

Our data collection was carried out in June - September 2014 and included 1200 persons. However, the current statistical analysis included on 910 respondents, aged 18-69, living in Baranya or Zala county in Hungary. Most respondents were living in cities, and the sample is representative of the Hungarian population regarding gender and age. The level of education in our sample was generally rather high: only $21.0 \%$ of the sample had less than secondary education. The form of work is also strongly connected to the previous fact - lower levels of education often go together with physical work. In our sample, active respondents only carried out sedentary work or light physical work. $50.6 \%$ of the respondents were living in marriage, the rate of divorced respondents was only $6.2 \%$, and the rate of widows was $4.1 \%$. Looking at the BMI values only, $46.1 \%$ of the female respondents had normal body figure and $3.1 \%$ were underweight. Thus more than half of the female respondents examined were overweight or obese. In men, the rate of respondents with underweight or normal BMI is 33.5\% while the rate of overweight and obese respondents was $66.5 \%$ (Table 1).

Table 1. Descriptive statistics

\begin{tabular}{|c|c|c|c|c|c|c|}
\hline & Female (n) & $\%$ & Male (n) & $\%$ & Total (n) & $\%$ \\
\hline Age groups & 471 & 51.8 & 439 & 48.2 & 910 & 100 \\
\hline $18-29$ & 97 & 20.6 & 98 & 22.3 & 195 & 21.4 \\
\hline $30-39$ & 93 & 19.7 & 101 & 23.0 & 194 & 21.3 \\
\hline $40-49$ & 89 & 18.9 & 90 & 20.5 & 179 & 19.7 \\
\hline $50-59$ & 100 & 21.2 & 89 & 20.3 & 189 & 20.8 \\
\hline $60-69$ & 92 & 19.6 & 61 & 13.9 & 153 & 16.8 \\
\hline Education (n) & 470 & 51.8 & 437 & 48.2 & 907 & 100 \\
\hline 8 years or less & 20 & $4.2 \%$ & 17 & $3.9 \%$ & 37 & 4.1 \\
\hline vocational school & 59 & $12.6 \%$ & 94 & $21.5 \%$ & 153 & 16.9 \\
\hline $\begin{array}{l}\text { high school degree and advanced vocatio- } \\
\text { nal school degree }\end{array}$ & 222 & $47.2 \%$ & 187 & $42.8 \%$ & 409 & 45.0 \\
\hline college-, university- or scientific degree & 169 & $36.0 \%$ & 139 & $31.8 \%$ & 308 & 34.0 \\
\hline $\begin{array}{l}\text { type of work among working adult } \\
\text { respondents }\end{array}$ & 287 & 46.9 & 325 & 53.1 & 612 & 100 \\
\hline $\begin{array}{l}\text { sedentary work with less than } 30 \text { minutes } \\
\text { of physical activity }\end{array}$ & 82 & 28.6 & 69 & 21.2 & 151 & 24.7 \\
\hline $\begin{array}{l}\text { sedentary work with at least } 30 \text { minutes of } \\
\text { physical activity }\end{array}$ & 114 & 39.7 & 137 & 42.2 & 251 & 41.0 \\
\hline light physical work & 91 & 31.7 & 119 & 36.6 & 210 & 34.3 \\
\hline Marital status & 464 & 51.6 & 436 & 48.4 & 900 & 100 \\
\hline single & 118 & 25.4 & 126 & 28.9 & 244 & 27.1 \\
\hline married & 224 & 48.3 & 231 & 53.0 & 455 & 50.6 \\
\hline cohabitated & 50 & 10.8 & 58 & 13.3 & 108 & 12.0 \\
\hline divorced & 38 & 8.2 & 18 & 4.1 & 56 & 6.2 \\
\hline widowed & 34 & 7.3 & 3 & 0.7 & 37 & 4.1 \\
\hline BMI groups & 466 & 51.6 & 437 & 48.4 & 903 & 100 \\
\hline underweight & 14 & 3.1 & 2 & 0.5 & 16 & 1.8 \\
\hline normal & 215 & 46.1 & 144 & 33.0 & 359 & 39.8 \\
\hline obese & 133 & 28.5 & 184 & 42.1 & 317 & 35.1 \\
\hline overweight & 104 & 22.3 & 107 & 24.4 & 211 & 23.3 \\
\hline
\end{tabular}




\section{Physical activity}

Looking at the socio-demographic determinants of physical activity, we first examined gender-related differences. We grouped the physical activity of the population examined into three categories based on the IPAQ-results: we considered physical activity low at $600 \mathrm{MET} /$ week, medium at $3000 \mathrm{MET} /$ week, and high at higher level of MET/week, in terms of work, transportation and physical activity carried out at home and in the free-time. As a result, $60.7 \%$ of the female population examined and $61.3 \%$ of the male population belonged to the high physical activity category; and only $7.7 \%$ of men and $5.7 \%$ of women belonged to the low physical activity category. No significant difference was found between men and women (Figure 1). Contrary to our results, the relevant literature in most of the cases reports significant difference between the two genders, which led us to continue our analysis. The detailed examination of physical activity according to activity types showed significant gender-differences in the following types of activities: men spend more time weekly doing physical activity related to work, activities around the house, and high-intensity sports, while women spend more time walking and doing household activities (Figure 2). This suggests that the basic differences lie in different PA activities, rather than in total PA levels.

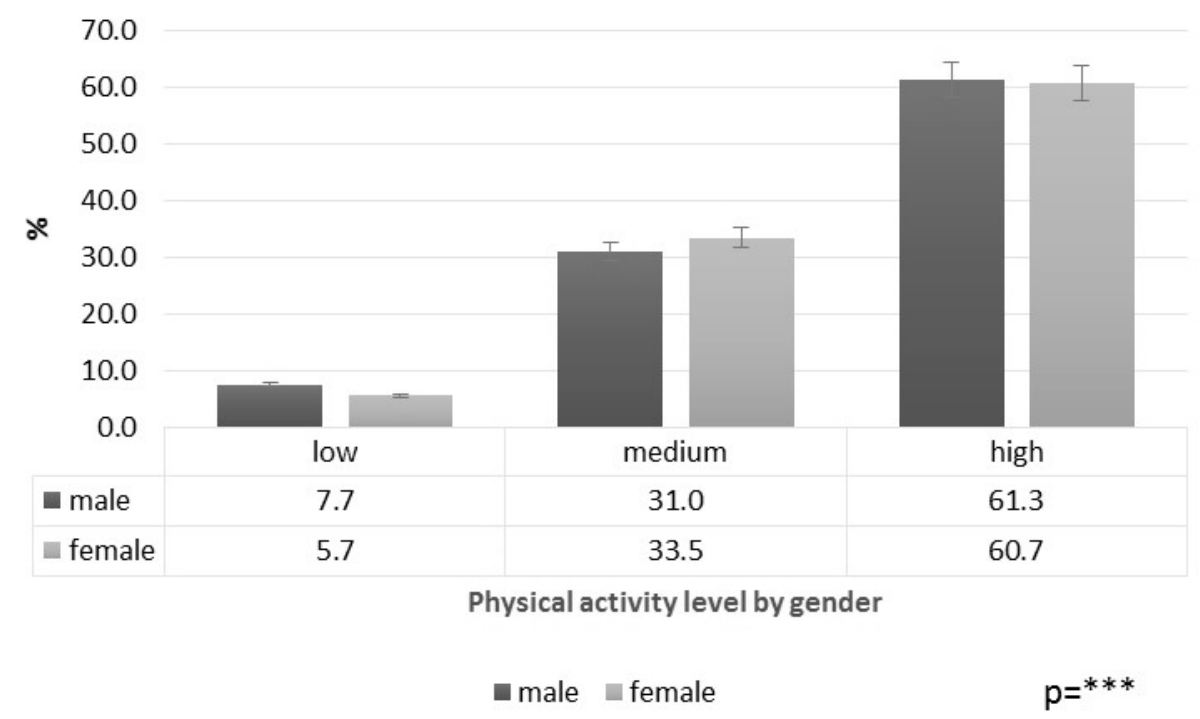

Figure 1. Physical activity level by gender among the adult population $\left({ }^{* * *} p>0.05\right)$

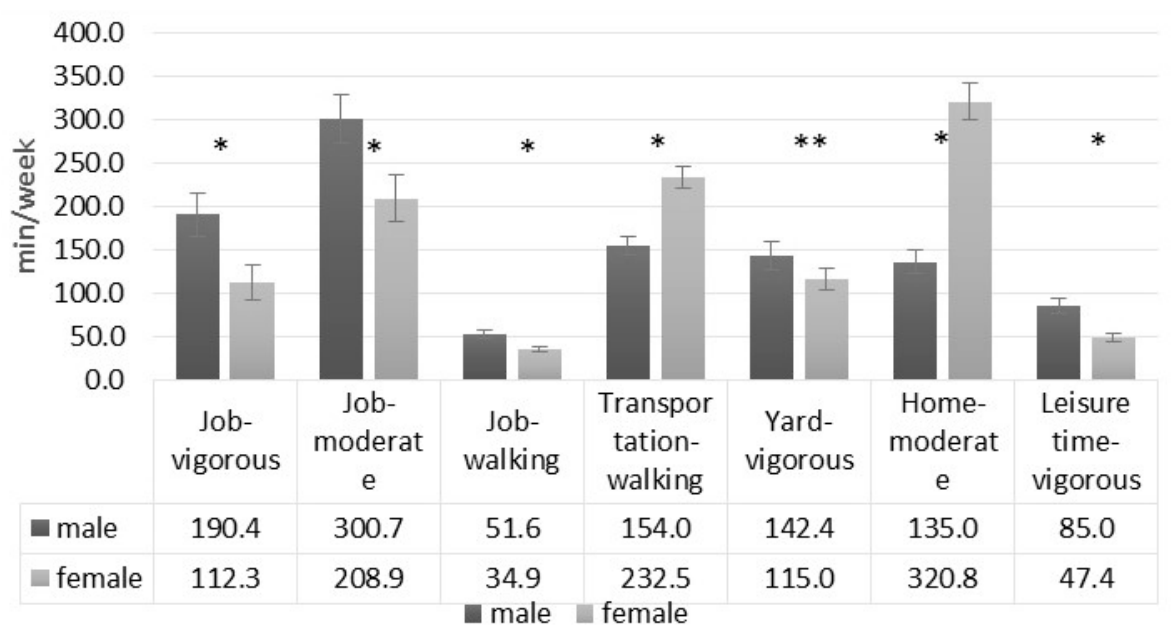

Figure 2. Physical activity by different types of activities according to gender $\left(\mathrm{p}<0.001^{*}, \mathrm{p}<0.05^{* *}\right)$

Following the examination according to gender, we analysed the physical activity rate of different age groups, and we found a significant correlation between age groups and the level of activity $(p=0.015)$. The low activity rate (10.8\%) of the $18-29$ year old age group is outstanding, which is the most unfavourable of all age groups. The 
most active age group was the 40-49 year olds, with a 67.0\% activity rate (Figure 3 ). Furthermore, we examined the connection between physical activity and marital status, and found that widows from the older generations have the lowest level of activity (13.5\%), and relationships can usually be associated with a higher activity rate $(\mathrm{p}<0.072)$ (Figure 4).

Finally, we examined the connection between physical activity rates and education and the type of work. Our results showed that lower level of education was connected to a higher level of inactivity (18.9\%), and the highest level of activity was to be found among respondents with vocational school duration. Our findings suggest that, the higher one's educational level was in our sample, the lower his physical activity rate was. However, in respondents with a higher educational degree, the rate of respondents with medium activity was higher (43.8\%), and only $6.2 \%$ was the rate of respondents with low physical activity (Figure 5). The type of work unambiguously shows the correlation between sedentary work and the level of physical activity $(\mathrm{p}<0.001)$ : sedentary lifestyle with less than 30 minutes of activity every day results in a lower physical activity rate in the adult population examined (Figure 6).

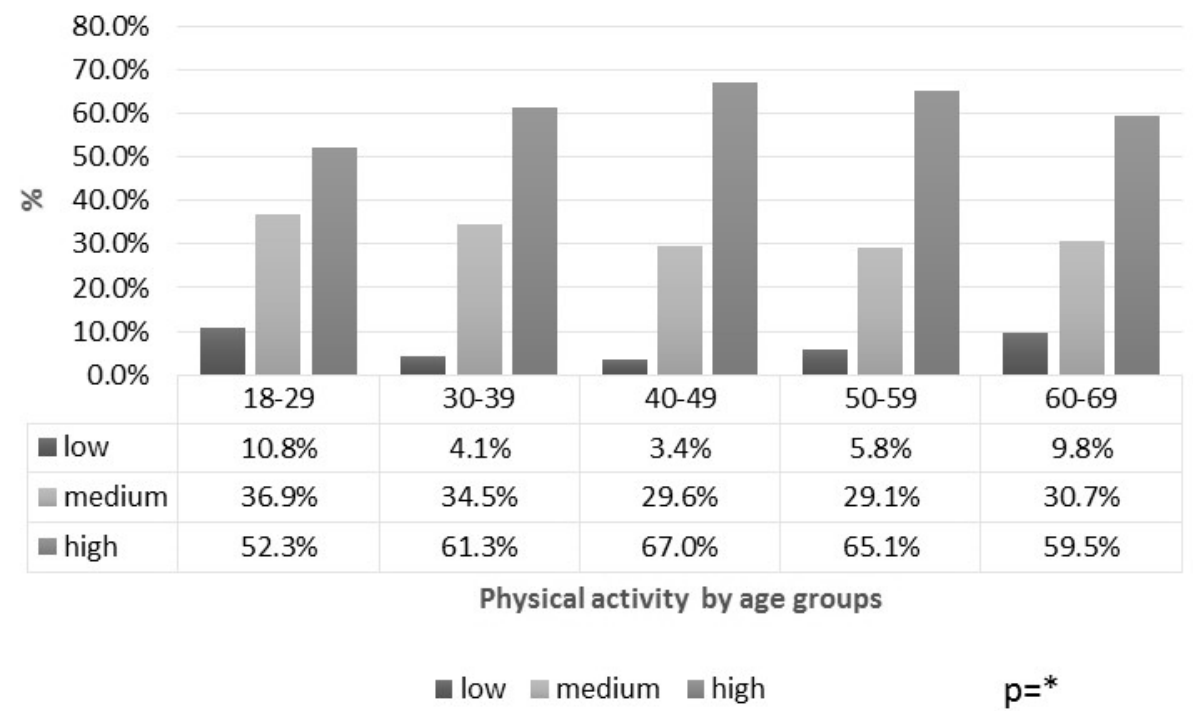

Figure 3. Physical activity level by age groups $\left(\mathrm{p}<0.001^{*}\right)$

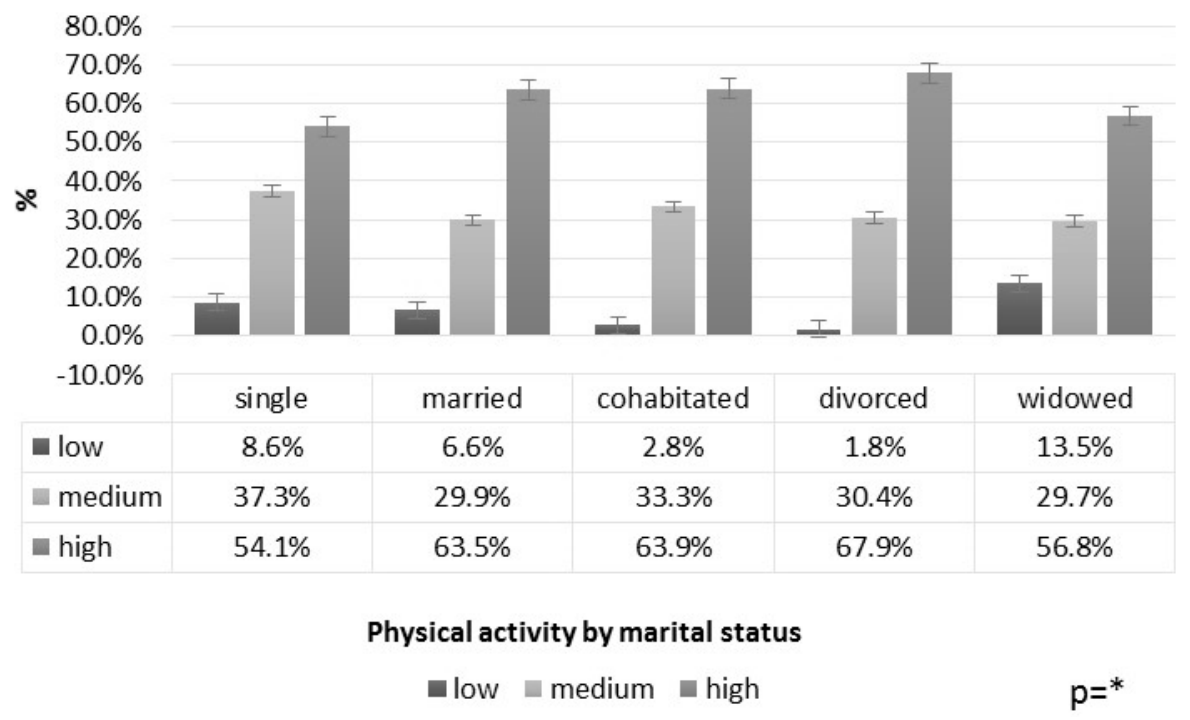

Figure 4. Physical activity level and marital status $\left(\mathrm{p}<0.001^{*}\right)$ 


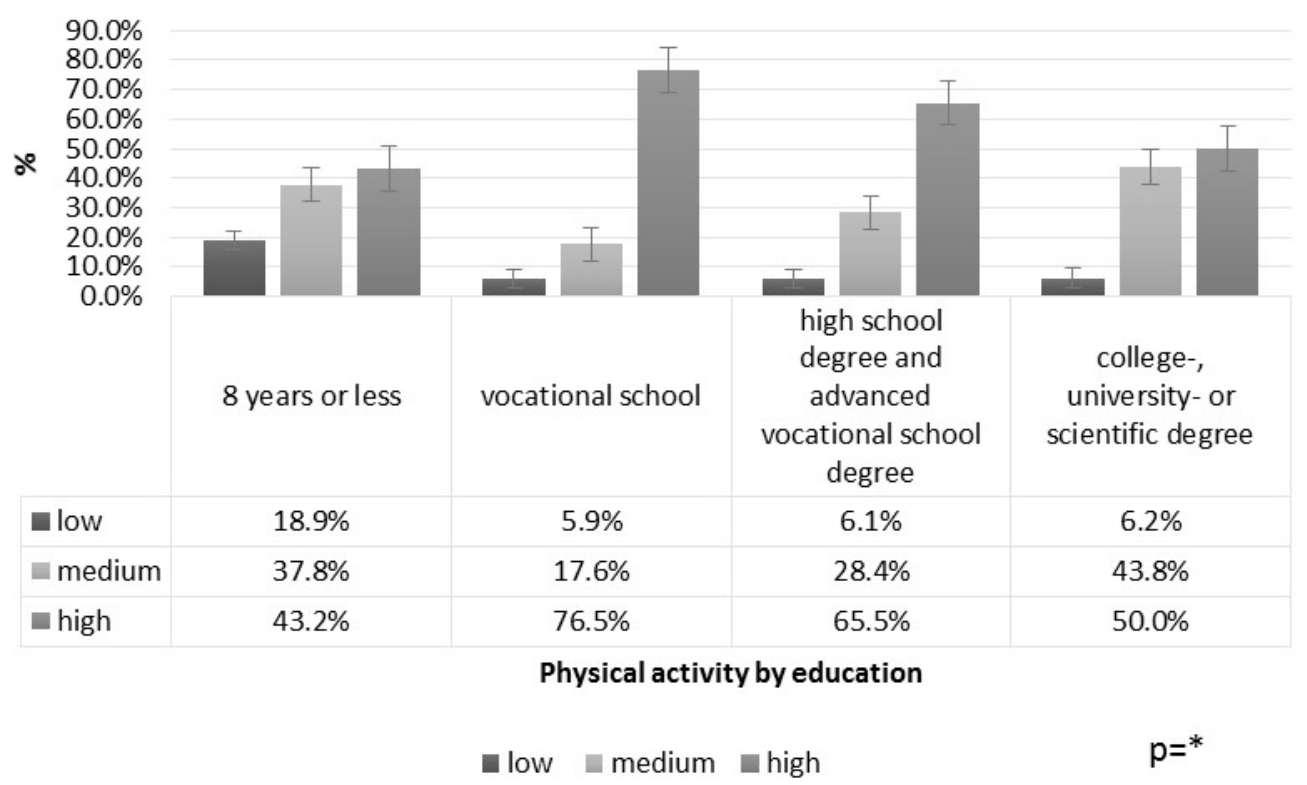

Figure 5. Association between physical activity and education level $\left(\mathrm{p}<0.001^{*}\right)$

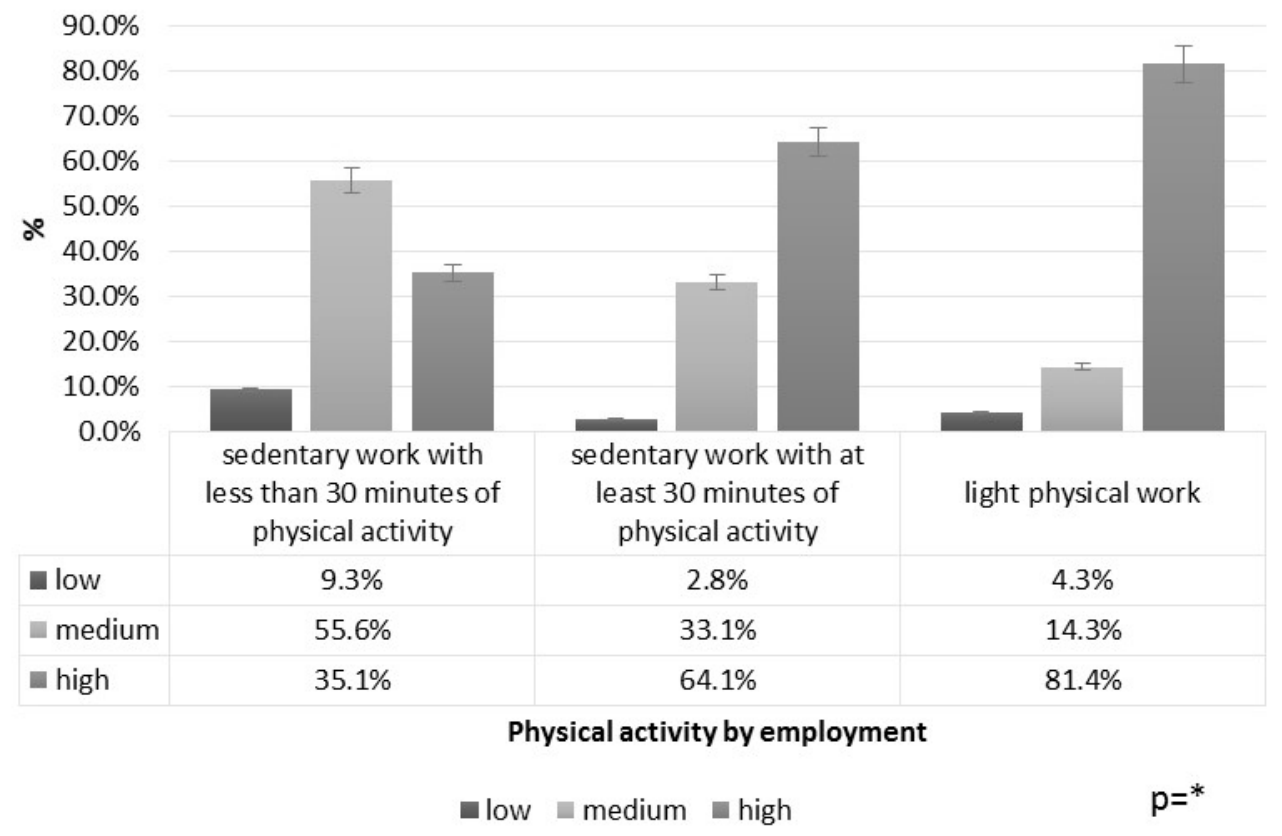

Figure 6. Relationship between physical activity level and employment form $\left(\mathrm{p}<0.001^{*}\right)$

\section{Discussion}

The population of our age- and gender-representative sample taken in two Hungarian counties (Baranya and Zala county, $\mathrm{N}=910$ ) in 2014 was highly educated, married, usually carrying out sedentary work. After the BMI-based categorisation we established four groups, and the rate of overweight or obese people was generally high: more than $50.8 \%$ of women and $66.5 \%$ of men. The high BMI scores were calculated based on the anthropometric values of weight and height. The unfavourable results were due to the inappropriate energybalance, i.e. die to inappropriate nutrition and physical activity. Inappropriate nutrition - despite high levels of physical activity - will cause high BMI level, usually highlighting overweight status, which has a negative effect on the health status and disposes individuals for diseases. Also, appropriate nutrition without the satisfactory level of physical activity will not be enough to positively influence the body composition parameters and health status. The current study presents the correlation between parameters of physical activity and demographic 
features, covering only parts of the analysis that was carried out regarding the energy balance research of the adult population in Baranya and Zala counties of Hungary.

Of all socio-demographic parameters we first analysed gender-related differences. Several studies reported significant differences in physical activity and health status according to gender $\left[26,27,28,{ }^{29},{ }^{30},{ }^{31}\right]$. Our results showed similar physical activity rate in both genders without significant difference, while - despite the amount of different activities - our extended analysis showed that women spend more time with walking and household works, and are less active during their work. In men, physical activity during work is higher, and they do more sports activities during their free-time which has higher MET-values, such as swimming, cycling at high speed, or running, according to which a significant difference was detected between the two genders.

Regarding the analysis of further socio-demographic features and physical activity, we should highlight the low activity level (10.8\%) of 18-29 year-old age group. This group, at the beginning of active age and with an assumingly good health, should pay attention to the physical activity to maintain good health. Another risk group is the older widows living alone, and also those carrying out sedentary work, and those with 8 years of primary education or less (low activity rate: 13.5\%). We should also note that the analysis summarised the effect of the examined socio-demographic parameters on physical activity however requires further examinations too for better understanding.

In previous studies, the rate of inactive adults was around 30\%. However, in our sample of two Hungarian counties we more favourable results, which - by the proven unfavourable anthropometric data - might refer to the disadvantages in subjective evaluation: our respondents might have rated their activity higher than it actually is. Nevertheless our results clearly show the differences in physical activity and the most important risk groups regarding inactivity. Evaluation of physical activity rates according to socio-demographic data provides an opportunity to unambiguously identify risk groups, and to develop specifically targeted intervention strategies to increase activity.

\section{References:}

1. Griera JL, Manzanares JM, Barbany M, Contreras J, Amigó P, Salas-Salvadó J. Physical Activity, energy balance and obesity. Public Health Nutrition 2007; 10(10A): 1194-1199.

2. Pavlik G. A rendszeres fizikai aktivitás szerepe betegségek megelőzésében, az egészség megőrzésében. Egészségtudomány. 2015; LIX. évfolyam, 2. szám, 1-16 (in Hungarian).

3. Apor P. Testedzéssel a megbetegedések ellen. Magyar Tudomány. 2012; 173. évf. 12. sz (in Hungarian).

4. Járomi M, Németh A, Kránicz J, Laczkó T, Betlehem J. Treatment and ergonomics training of work-related lower back pain and body posture problems for nurses. J Clin Nurs. 2012; 21(11-12):1776-84.

5. Escalante Y, Karianne Backx K, Saavedra JM. Relationship Between Break-Time Physical Activity, Age, and Sex in a Rural Primary Schools, Wales UK. Journal of Human Kinetics. 2014; 40: 227-234.

6. Bajsz V, Sió E, Tóthné Steinhausz V, Karamánné Dr, Pakai A, Császárné Gombos G. Egy multinacionális cég egészségfelmérése a munkahelyi stressz tükrében. Egészségfejlesztés LIV. évfolyam 2013; 5-6. szám (in Hungarian).

7. Ramírez-Vélez R, González-Ruíz K, García S, Agredo-Zúñiga RA. Sex differences in the relationship between vigorous vs. moderate intensity exercise and risk markers of overweight and obesity in healthy adults. Endocrinol Nutr. 2012; 59(8): 491-5.

8. Neumann NU, Frasch K. The benefits of physical activity. MMW Fortschr Med, 2008; 11;150(36-37): 38-40.

9. Preamble to the Constitution of the World Health Organization as adopted by the International Health Conference, New York, 19-22 June, 1946; signed on 22 July 1946 by the representatives of 61 States (Official Records of the World Health Organization, no. 2, p. 100) and entered into force on 7 April 1948.

10. Pikó B. Egyenlőtlenségek az egészségi állapotban Századvég 1998; 3. évf. 11. sz. (in Hungarian).

11. Oláh A, Sándor J, Boncz I, Betlehem J, Sebestyén A, Kisbenedekné Gulyás, et al. Kistérségi egyenlőtlenségek az otthoni szakápolás vonatkozásában a Dél-Dunántúlon. Nővér, 2004; 17: 17-25 (in Hungarian).

12. Boncz I, Vajda R, Ágoston I, Endrei D, Sebestyén A. Changes in the health status of the population of Central and Eastern European countries between 1990 and 2010. Eur J Health Econ, 2014; 15: 137-141.

13. Ács P, Hécz R, Paár D, Stocker M. A fittség (m)értéke - A fizikai inaktivitás nemzetgazdasági terhei Magyarországon. 2011; Közgazdasági Szemle, 58. évfolyam/7-8. szám: 689-708 (in Hungarian).

14. Tahin T, Jeges S, Lampek K. Iskolai végzettség és egészségi állapot Demográfia 2000; 43(1): 70 -93 (in Hungarian).

15. Aaron DJ, Storti KL, Robertson RJ, Kriska A, LaPorte R. Longitudinal study of the number and choice of leisure time physical activities from mid to late adolescence. Arch Pediatr Adolesc Med, 2002; 156: 1075-1080. 
16. Pikó BF, Fitzpatrick KM. Socioeconomic status, psychosocial health and health behaviors among Hungarian adolescents. Eur J Publ Health, 2007; 17: 353-360.

17. Bergier J, Kapka-Skrzypczak L, Biliński P, Paprzycki P. Physical activity of Polish adolescents and young adults according to IPAQ: a population based study. Annals of Agricultural and Environmental Medicine 2012; 19(1): 109-115.

18. Hye-cheon Kim K, Sobal J. Religion, social support, fat intake, and physical activity. Public Health Nutrition 2004; 7(6): 773-781.

19. Hosseinpoor AR, Stewart Williams J, Amin A, Araujo de Carvalho I, Beard J, et al. Social Determinants of Self-Reported Health in Women and Men: Understanding the Role of Gender in Population Health. PLoS ONE. 2012; 7(4): e34799. doi:10.1371/journal.pone.0034799

20. Pinto Pereira SM, Geoffroy MC, Power C. Depressive symptoms and physical activity during 3 decades in adult life: bidirectional associations in a prospective cohort study. JAMA Psychiatry. 2014; 1;71(12): 137380.

21. Parks SE, Housemann RA, Brownson RC. Differential correlates of physical activity in urban and rural adults of various socioeconomic backgrounds in the United States. J Epidemiol Community Health. 2003; Jan;57(1): 29-35.

22. Ortiz-Hernández L, Ramos-Ibanez N. Sociodemographic factors associated with physical activity in Mexican adults. Public Health Nutrition. 2010; 13(7): 1131-1138.

23. Pettee KK, Brach JS, Kriska AM, Boudreau R, Richardson CR, Colbert LH, et al. Influence of marital status on physical activity levels among older adults. Med Sci Sports Exerc. 2006; 38(3): 541-6.

24. Lee PH, Macfarlane DJ, Lam TH, Stewart SM. Validity of the international physical activity questionnaire short form (IPAQ-SF): A systematic review. International Journal of Behavioral Nutrition and Physical Activity. 2011; 8: 115.

25. Lachat CK, Verstraeten R, Khanh le NB, Hagströmer M, Khan NC, Van Ndo A, et al. Validity of two physical activity questionnaires (IPAQ and PAQA) for Vietnamese adolescents in rural and urban areas. Int J Behav Nutr Phys Act. 2008; 10;5: 37.

26. Bourne P, Brooks D. Gender, women and health: Gendered health differences. International Journal of Colaborative Research on Internal Medicine \& Public Health. 2011; 3(7), 550-574.

27. Nakamura PM, Teixeira IP, Smirmaul BPC, Sebastião E, Papini CB, Gobbi S, et al. Health related quality of life is differently associated with leisure-time physical activity intensities according to gender: a cross-sectional approach. Health and Quality of Life Outcomes 2014; 12: 98.

28. Yasunaga A, Togo F, Watanabe E, Park H, Shephard RJ, Aoyagi Y. Yearlong physical activity and health-related quality of life in older Japanese adults: the Nakanojo Study. J Aging Phys Act. 2006; 14(3): 288-301.

29. Bergier J. The level of physical activity in society today - the problem of modern civilisation: (research overview). Human and Health. 2012; 6(1): 3-22.

30. Cerin E, Cain KL, Conway TL, Van Dyck D, Hinckson E, Schipperijn J, et al. Neighbourhood environments and objectively measured physical activity in 11 Countries. Med Sci Sports Exerc. 2014; 46(12): 2253-2264.

31. Sugiyama T, Cerin E, Owen N, Oyeyemi A, Conway TL, Van Dyck D, et al. Perceived HPC-00014-2016-01 neighbourhood environmental attributes associated with adults? recreational walking: IPEN Adult study in 12 countries. Health \& Place. 2014; 28: 22-30. 